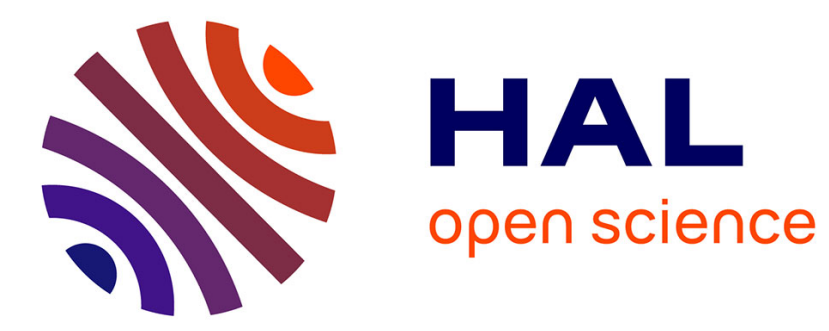

\title{
Analysis of 3D structural root architecture data of trees grown on slopes
}

\author{
Frederic F. Danjon, D.H. Barker, Michael Drexhage, Alexia Stokes
}

\section{To cite this version:}

Frederic F. Danjon, D.H. Barker, Michael Drexhage, Alexia Stokes. Analysis of 3D structural root architecture data of trees grown on slopes. 2. International Symposium on plant growth modelling, simulation, visualization and applications, Nov 2006, Beijing, China. 1 p. hal-02814096

\section{HAL Id: hal-02814096 \\ https://hal.inrae.fr/hal-02814096}

Submitted on 6 Jun 2020

HAL is a multi-disciplinary open access archive for the deposit and dissemination of scientific research documents, whether they are published or not. The documents may come from teaching and research institutions in France or abroad, or from public or private research centers.
L'archive ouverte pluridisciplinaire HAL, est destinée au dépôt et à la diffusion de documents scientifiques de niveau recherche, publiés ou non, émanant des établissements d'enseignement et de recherche français ou étrangers, des laboratoires publics ou privés. 


\section{Submission Form PMA06}

\section{Analysis of 3D structural root architecture data of trees grown on slopes}

Frédéric DANJON, David H. BARKER, Michael DREXHAGE, Alexia STOKES

\section{Abstract:}

The soil reinforcement by plant roots is of primary importance in landslide occurrence in natural slopes or in man-made slopes. Influence of slope on coarse root architecture and potential influence of tree root architecture on shallow-seated slope reinforcement have rarely been studied because of the lack of suitable measurement methods. Three-dimensional digitising in situ and software devoted to plant architecture analysis provide now efficient method for these purposes.

A methodology to analyse 3D coarse root system architecture of trees grown on slope is presented in this poster. The methodology is applied to two Quercus alba trees located in sloping ground, exposed in situ by using high-velocity air jetting.

We propose the following additions to the published 3D root architecture data analysis (e. g. Danjon et al. Plant Soil 211 - 1999, Danjon et al. New Phytol 168 2005):

- root dry weight was used instead of root volume. The dry weight of each root segments was computed from root density data gained on 5 root samples representing five diameter classes.

- to compute root dry weight per circular sector or by depth, all the measured root segments were divided into $1 \mathrm{~cm}$ long virtual sub-segments.

- To derive root characteristics as a function of distance to the soil surface, and to compute characteristics of root crossing planes parallel to the slope, the root system data coordinates were rotated around the $Y$ axis

- The influence of slope was assessed by examining slope oriented heterogeneities in root length and volume as well as SRL, branching angle and inter-lateral length.

- And using 1D cumulative root length and volume distributions as a function of distance to the soil surface, radial distance and azimuth, upslope and downslope

Potential contribution to soil reinforcement

Three types of figures visualizes the spatial distribution of parameters of roots intersecting planes parallel to the slope - i. e. potential sliding planes:

1) one dimensional distributions of both upslope and downslope characteristics as a function of distance to the soil surface including characteristics related to soil reinforcement (e. g. root number, cumulative cross sectional area, mean diameter, mean angle toward soil surface, mean length to the previous branch).

2) Multiple $2 D$ root impact maps on 4 planes parallel to the slope

3) Root area ratio in forty surfaces of unequal size centered on the trees on 4 planes parallel to the slope at $30 \mathrm{~cm}$ depth intervals.

These graphs provided an overview of the 3D structure of root reinforcement. The data may be manipulated to determine critical failure plane depth and inclination.

\section{Poster}

\section{Topic: 3D structural root architecture data of trees grown on slopes}

Contact Name: F. DANJON

Email address:

fred@pierroton.inra.fr
Inst./Univ./Comp. : INRA

Tel. (0)5 57122845

Fax. (0)5 566802

23 